\title{
Allergic airway disease in Italian bakers and pastry makers
}

\author{
R De Zotti, F Larese, M Bovenzi, C Negro, S Molinari
}

\section{Abstract}

A survey was carried out on respiratory symptoms and skin prick test response to common allergens (atopy), storage mites, and occupational allergens among 226 bakers and pastry makers from 105 small businesses in northern Italy. Atopy was present in 54 workers (23.4\%); 40 workers $(17 \cdot 7 \%)$ were skin positive to at least one storage mite, $27(11.9 \%)$ to wheat flour and $17(7 \cdot 5 \%)$ to $\alpha$-amylase. Work related asthma was reported by 11 (4.9\%) workers and rhinoconjunctivitis by $31(17 \cdot 7 \%)$; 22 workers (10.2\%) complained of chronic bronchitis. The distribution of skin prick test results among bakers and among 119 white collar workers did not indicate (by logistic analysis) an increased risk for bakers to skin sensitisation to common allergens, storage mite, or to a group of five flours. Sensitisation to wheat flour, on the other hand, was present only among exposed workers. Skin sensitisation to occupational allergens was significantly associated with atopy $(p<0.001)$, smoking habit $(p=0.015)$, and work seniority $(p=$ $0.027)$. The risk of work related symptoms was associated with sensitisation to wheat or $\alpha$-amylase, and with atopy, but not with sensitisation to storage mites, work seniority, or smoking habit. The results of the study indicate that there is still a significant risk of allergic respiratory disease among Italian bakers. Not only wheat allergens, but also $\alpha$-amylase must be considered as causative agents, although sensitisation to storage mites is not important in the occupational allergic response. Atopy must be regarded as an important predisposing factor for skin sensitisation to occupational allergens and for the onset of symptoms at work. The data confirm that for effective prevention, greater care should be taken not only in limiting environmental exposure, but also in identifying susceptible people.

(Occup Environ Med 1994;51:548-552)

The first scientific description of bakers' asthma was given by Ramazzini in 1700 in $D e$ morbis artificum diatriba, and the first systematic investigation in the bakery trade was by Baagoe in $1933 .{ }^{1}$ Since then, allergic disease in bakers has been studied by many authors and numerous potential allergens have been described. The most often recognised source of occupational disease among these workers is wheat, ${ }^{2-4}$ but other cereals, mites, weevils, moulds, and enzymes have been proposed as occupational allergens. ${ }^{56}$

Both environmental and host factors are important determinants of occupational asthma for workers exposed to wheat or other high molecular weight substances. Nevertheless, whereas there is agreement on the role of environmental prevention there is still debate on the applicability of prevention policies based on the identification of personal predisposing factors, such as atopy. ${ }^{7-9}$

The present investigation was undertaken to clarify the role of some occupational allergens among Italian bakers and pastry makers and to verify the role of certain personal characteristics as indicators of susceptibility to allergic occupational disorders.

\section{Methods}

We tested 226 workers, representing $82 \%$ of all exposed people from 105 bakeries and pastry shops in four health districts of northern Italy. All subjects working at least four hours per day making bread or cakes completed a questionnaire on occupational exposure, smoking habit, and personal history of respiratory symptoms. Smokers were defined as those who had smoked at least one cigarette a day or equivalent in other tobacco products for at least one year and ex-smokers as those who had ceased smoking at least two years before the study. Chronic bronchitis was defined as cough productive of sputum on most days for at least three months of each year for two or more consecutive years. Work related asthma was defined as the presence of attacks of cough, wheeze, and dyspnoea that appeared only at work or become significantly worse there. Work related rhinitis was defined as the presence of sneezing or itchy, running nose during the working period.

Skin prick tests were performed with a range of baking related and common allergens (Lofarma, Millan, Italy); the positive control was histamine dihydrogen chloride and the negative control was $1 \%$ glycerinate solution. All tests were read at 15 minutes and a weal of $3 \mathrm{~mm}$ or more was measured as positive. Subjects were classified as atopic if they had at least one positive response to grass pollens, house dust mites Dermatophagoides pteronyssinus or D Farinae, or cat or dog danders. We analysed storage mites separately to evaluate their possible role as occupational allergens. 
Table 1 Characteristics of bakers and pastry makers $(n=226)$

\begin{tabular}{lc}
\hline Age (y) (mean (SD)) & $39 \cdot 4(14 \cdot 1)$ \\
Work seniority (y) (mean (SD)) & $17 \cdot 9(14 \cdot 3)$ \\
Smoking: & $36 \cdot 3$ \\
Current smokers (\%) & $50 \cdot 9$ \\
Never smokers (\%) & $12 \cdot 8$ \\
Ex-smokers (\%) & $13 \cdot 7$ \\
Work related symptoms: & $4 \cdot 9$ \\
Rhinoconjunctivitis (\%) & $10 \cdot 2$ \\
Asthma (\%) & $23 \cdot 9$ \\
Chronic bronchitis (\%) & $11 \cdot 9$ \\
Prick tests: & $7 \cdot 5$ \\
Common allergens (\%) & $13 \cdot 7$ \\
Wheat (\%) & $17 \cdot 7$ \\
Amylase (\%) & \\
Wheat and/or $\alpha$-amylase (\%) & \\
Storage mites (\%) & \\
\hline
\end{tabular}

Subjects were considered "storage mite positive" if they had a positive response to at least one of the four mites tested (Acarus siro, Glycyphagus domesticus, Lepidoglyphus destructor, Thyrophagus putrescentiae).

As occupational antigens we tested wheat, rye, barley, soybean, maize flours (Lofarma, Milan, Italy) and $a$-amylase from Aspergillus oryzae at a concentration of $1 \mathrm{mg} / \mathrm{ml}$; before testing $a$-amylase among the bakers, we tested it in 20 common allergic patients without finding any positive skin response. We also did prick tests with common allergens and the same flours in 119 white collar workers.

\section{STATISTICAL PROCEDURE}

Data analysis was performed with BMDP/ Dynamic software (Release 7.0). Continuous data were summarised as means (SD). The difference between means was tested by Student's $t$ test. The $\chi^{2}$ test was applied to data tabulated in $2 \times 2$ contingency tables. The association between the response and the predictor variables was assessed by multivariate logistic regression analysis. Logistic regression coefficients and standard errors were used to obtain the prevalence odds ratios (ORs) and $95 \%$ confidence intervals (95\% CIs) adjusted for several potential confounders. The predictor variables entered the logistic model as categorical covariates, except for age and work seniority, which were used as continuous covariates. Stepwise selection of predictor variables was based on the likelihood ratio $\chi^{2}$ test. The goodness of fit of the logistic models was assessed by the HosmerLemershow $\chi^{2}$ statistic.

Results

All 226 subjects had occupational exposure to wheat flour and often used baking additives to improve and hasten the baking process. Table 1 shows the characteristics of the entire group (175 men and 51 women); the women's age (38.5 (SD 13.6)) and work seniority $(15 \cdot 2$ (SD $1 \cdot 66)$ years were similar to those of the men, but less of them were smokers $(19.6 \% v 36.3 \%, \mathrm{p}<0.001)$. In all, 54 $(23.9 \%)$ of the group were atopic, $24(11.9 \%)$ were skin test positive to wheat flour, and 17 $(7 \cdot 5 \%)$ to $a$-amylase; $40(17 \cdot 7 \%)$ were sensitised to at least one kind of storage mite.

Table 2 shows the distribution of skin prick test results among bakers compared with the 119 white collar workers. Odds ratios, adjusted for age, smoking habit, and sex, were estimated by logistic modelling, with separate analyses for skin positivity to common allergens, to storage mites and to the five different flours. The results did not indicate an increased risk of sensitisation among bakers compared with the white collar workers, with the exception of wheat flour, which when tested alone, gave a positive skin response only among bakers.

Multiple skin sensitisation was common among all atopic workers and also among the 31 workers sensitised to occupational allergens. Monosensitisation to wheat was present in seven workers, and to $a$-amylase only in one, whereas the other 23 had multiple skin reactions to occupational or common allergens. Twenty of the 31 workers sensitised to occupational allergens were also symptomatic at work.

Wheat flour allergen, although producing a skin reaction more often than $a$-amylase, gave less pronounced weals: in fact the diameters of the $a$-amylase induced weals nearly always exceeded $5 \mathrm{~mm}$ (14/17), whereas only four of the 27 cases sensitised to wheat had three weals exceeding $5 \mathrm{~mm}$. The association between skin sensitisation to occupational allergens (wheat flour and $a$-amylase) and several predictors (sex, work seniority, smoking habit, atopy and sensitisation to storage mites) was assessed by logistic regression analysis (table 3). Skin sensitisation to occupational allergens was significantly associated with atopy $(p<$ $0.0001)$, cigarette smoking $(p=0.015)$ and work seniority $(p=0.027)$. Within the male subgroup the results of the logistic analysis were similar, confirming an association between occupational skin sensitisation and atopy $(\mathrm{OR}=5 \cdot 30,95 \% \mathrm{CI}=1 \cdot 68-16 \cdot 7)$.

Allergic respiratory symptoms at work were reported by 42 workers ( 39 men and three women). Rhinitis, often associated with conjunctivitis, was the most common complaint

Table 2 Skin prick tests in bakers $(n=226)$ and white collar workers $(n=119)$

\begin{tabular}{|c|c|c|c|}
\hline \multirow[b]{2}{*}{ Positive skin tests } & \multirow{2}{*}{$\begin{array}{l}\text { Bakers } \\
\text { No (\%) }\end{array}$} & \multicolumn{2}{|c|}{ White collar workers } \\
\hline & & No $(\%)$ & OR $(95 \% C I)^{\star}$ \\
\hline $\begin{array}{l}\text { Common allergens } \\
\text { (pollens, house dust mites, danders) }\end{array}$ & $21(9 \cdot 3)$ & $20(16 \cdot 8)$ & $0.53(0.26-1.08)$ \\
\hline $\begin{array}{l}\text { Common allergens } \\
\text { and storage mites }\end{array}$ & $33(14 \cdot 6)$ & $17(14 \cdot 3)$ & $1.01(0.51-2.01)$ \\
\hline $\begin{array}{l}\text { Storage mites } \\
\text { Flours (wheat, rye } \\
\text { soybean, barley, maize) }\end{array}$ & $\begin{array}{c}7(3 \cdot 1) \\
49(21 \cdot 7)\end{array}$ & $\begin{array}{l}3(2 \cdot 5) \\
13(10 \cdot 9)\end{array}$ & $\begin{array}{l}1.33(0.31-5.74) \\
1.93(0.96-3.91)\end{array}$ \\
\hline
\end{tabular}

Table 3 Skin sensitisation to wheat flour and a-amylase in relation to storage mites sensitisation, atopy, sex, smoking habit, and work seniority among 226 bakers

\begin{tabular}{lll}
\hline Predictors & $O R$ & $(95 \% C I) t$ \\
\hline Storage mite sensitisation & 1.83 & $(0.59-5 \cdot 70)$ \\
Atopy & $5 \cdot 11$ & $(1 \cdot 69-15 \cdot 5)^{\star \star \star}$ \\
Sex & 2.97 & $(0.62-14 \cdot 2)$ \\
Smoking habit & 2.67 & $(1 \cdot 14-6 \cdot 25)^{\star \star}$ \\
Work seniority & 1.03 & $(1.00-1 \cdot 06)^{\star}$ \\
\hline${ }^{\star} \mathrm{p}=0.027 ;{ }^{\star \star} \mathrm{p}<0.015 ;{ }^{\star \star} \mathrm{p}<0.0001$. & \\
$\dagger$ tEstimated by logistic modelling. &
\end{tabular}


Table 4 Characteristics of symptomatic and asymptomatic bakers

\begin{tabular}{lll}
\hline & \multicolumn{2}{l}{ Work related symptoms } \\
\cline { 2 - 3 } & $\begin{array}{l}\text { Positive } \\
(n=42)\end{array}$ & $\begin{array}{l}\text { Negative } \\
(n=182)\end{array}$ \\
\hline Age (y) (mean (SD)) & $39 \cdot 1(11 \cdot 9)$ & $39 \cdot 5(14 \cdot 6)$ \\
Work seniority (y) (mean (SD)) & $17 \cdot 3(13)$ & $18(14 \cdot 5)$ \\
Smokers (\%) & $42 \cdot 8$ & $34 \cdot 8$ \\
Positive skin tests: & $35 \cdot 7$ & $13 \cdot 6^{\star}$ \\
Storage mites (\%) & $42 \cdot 9$ & $4^{\star} \cdot 9^{\star}$ \\
Wheat (\%) & 28.6 & $2 \cdot 7^{\star}$ \\
a-Amylase (\%) & $47 \cdot 6$ & $6^{\star}$ \\
Wheat + a-amylase (\%) & $52 \cdot 4$ & $17^{\star} \cdot 4^{\star}$ \\
Common allergens (\%) & $14 \cdot 3$ & $9 \cdot 2$ \\
Chronic bronchitis (\%) & & \\
\hline ॠ $<0.001$. & &
\end{tabular}

(13.7\%), whereas asthma was reported by 11 workers $(4 \cdot 9 \%)$. Personal atopy and positive skin response to storage mites, wheat flour, or $a$-amylase were more common among symptomatic than among asymptomatic workers, whereas age, work seniority, frequency of current smoking, and chronic bronchitis were similar in the two groups (table 4). When atopy and symptoms at work were assessed as four groups according to work seniority, however, it was clear that the number of atopic and symptomatic workers decreased in those groups with occupational exposure exceeding nine years (figure). In particular, there were $14.3 \%(4 / 28)$ symptomatic workers in the group with less than three years of exposure; this number rose to $24 \cdot 2 \%(13 / 53)$ in the group with three to nine years of work seniority, but decreased again to about $17 \%$ (13/75 and $12 / 70$ respectively) in the subsequent groups.

The association between work related symptoms and predictors including sex, work seniority, smoking habit, and the skin prick tests was assessed by logistic regression analysis. The skin prick test results were used to identify three groups of workers (table 5): group 1, skin negative to both common and occupational allergens (154 cases); group 2, atopic by skin prick, but negative to wheat flour and amylase (41 cases); and group 3, skin prick tests positive both to wheat flour or $a$-amylase and to common allergens (31 cases). Sex, smoking, and work seniority were not associated with symptoms at work. The negative regression coefficient for work seniority $(-0.033)$ confirmed a decreased prevalence of symptomatic people at work among those with prolonged exposure. Compared with group 1 , workers in group 2

Atopy and work related symptoms (WRS) by work seniority among 226 bakers.
Table 5 Association between work related symptoms and skin sensitisation to common (atopy) and occupational allergens (wheat, $\alpha$-amylase)

\begin{tabular}{llc}
\hline Skin prick test & No (\%) & OR $(95 \%$ CI) \\
\hline $\begin{array}{l}\text { Atopy (-) } \\
\text { occupational allergens (-) }\end{array}$ & $154(68 \cdot 1)$ & $1(-)$ \\
$\begin{array}{l}\text { Atopy (+) } \\
\text { occupational allergens (-) }\end{array}$ & $41(18 \cdot 1)$ & $3 \cdot 46(1 \cdot 29-9 \cdot 31)$ \\
Occupational allergens (+) & $31(13 \cdot 7)$ & $21 \cdot 3(7 \cdot 79-58 \cdot 0)$ \\
\hline
\end{tabular}

Estimated by logistic modelling.

had a significantly greater OR $(3 \cdot 46 ; 95 \% \mathrm{CI}=$ 1.29-9.31); however, the risk for symptoms at work was much higher among workers with sensitisation to at least one occupational allergen (group 3; $\mathrm{OR}=21.3 ; 95 \% \mathrm{CI}=$ $7 \cdot 79-58)$. When compared with group 2 , the workers in group 3 showed an OR of 6.82 $(95 \% \mathrm{CI}=2 \cdot 08-22 \cdot 3)$.

The results were similar when only men were tested: for group $1 v$ group 2 the OR was $4.05(95 \% \mathrm{CI}=1.44-11 \cdot 4)$; for group $1 v$ group 3 the $\mathrm{OR}$ was $20.9(95 \% \mathrm{CI}=$ $7 \cdot 37-59 \cdot 1)$.

Chronic bronchitis was reported by 22 bakers $(10 \cdot 2 \%)$. The disease was significantly associated with smoking habit $(O R=11 \cdot 3$, $95 \% \mathrm{CI}=3 \cdot 23-39 \cdot 2)$ and age $(\mathrm{OR}=1 \cdot 57$, 95\% CI $=1 \cdot 11-2 \cdot 22$ ), but not with sex and skin sensitisation to common and occupational allergens.

\section{Discussion}

Bakers' asthma is one of the oldest and most common occupational respiratory diseases in many countries ${ }^{1011}$ but there are still few epidemiological studies. ${ }^{12-14}$

In Italy, bread and pastry making is often a family based activity, as shown by Chamber of Commerce data: in the first six months of $1992,50.6 \%$ of this kind of activity had one to two employees, $45 \cdot 3 \%$ from three to nine, and only $4.1 \% 10$ or more workers. This makes it more difficult to collect data regarding health conditions among this population, and causes an underestimation of occupational disease among workers in small concerns. This is indicated by figures from the Italian Institute for Occupational Insurance, which show that $70 \%$ of cases of bakers' asthma receiving compensation were employees of large concerns whereas only $30 \%$ were artisans. ${ }^{15}$

The major allergen responsible for allergic respiratory disease in the baking industry is in wheat flour, ${ }^{2316}$ and skin sensitisation to wheat allergens has been found in as many as $90 \%$ of bakers in selected groups of symptomatic workers and in $4-21 \%$ of workers in epidemiological studies. ${ }^{10-12}$ In the past few decades, however, there has been an increasing use of baking additives to improve the rising of the dough and the quality of bread, pastry, and fancy cakes and this represents a new source of risk. Some of these additives contain powdered enzymes, which seem to be responsible for allergic respiratory disease. ${ }^{17-20}$

Among our sample of 226 workers, sensitisation to wheat flour, which was present in $11.9 \%$ of cases (24 workers), emerged as a 
specific indicator of occupational exposure; in fact, there was not one positive response to the wheat allergen among the white collar workers. The skin response to other flours tested was less specific. Sensitisation to $a$ amylase from Aspergillus oryzae, the most common glycolytic enzyme used in the baking industry, was documented in 17 workers $(7 \cdot 5 \%)$. The potency of the enzyme in inducing a cutaneous reaction is indicated by the prick test responses, with weals nearly always bigger than those caused by wheat flour, nevertheless, it should be stressed that 16 of the 17 workers skin positive to the enzyme were also sensitised to wheat flour or other allergens.

As was to be expected, skin sensitisation to occupational allergens (wheat flour and $a$ amylase) emerged as the most important predictor of symptoms at work, but as in many cases there was a positive response to both allergens at the same time, it was impossible to speculate on the role of each one in inducing the symptoms. In one case, however, work related rhinitis was accompanied by sensitisation to $a$-amylase alone, suggesting a specific role for the enzyme. Our rates of $a$-amylase sensitisation were lower than those reported by Brisman and Belin ${ }^{20}$ in a factory of semimanufactured products for restaurants and bakeries, but that study used higher concentrations of allergen. For symptomatic workers, on the other hand, our rates were similar to those found by Baur et $a l^{17}$ among asthmatic bakers. Although wheat flour is the main source of occupational exposure for bakers, and exposure to the enzyme is much lower, ${ }^{20} 21$ these results indicate that the presence of $a$ amylase in the baking process needs careful evaluation and more precise information is needed about the products used in the bakery. $a$-Amylase should be included in the list of occupational substances to be tested during medical surveys of these workers and further studies should be carried out to better define its characteristics, and clarify the relation between skin reaction to the enzyme, sensitisation to wheat flour, and atopy.

Storage mites, which some authors have suggested are an important cause of sensitisation among bakers ${ }^{62}$ did not seem to be particularly important in causing an allergic response among our workers; there was no difference in the risk of sensitisation for bakers when compared with white collar workers. In both groups, positive skin reactivity to storage mites was often associated with that to other common allergens and among those few cases with sensitisation to storage mites alone, there were no bakers with work related symptoms. Our results confirm, therefore, that storage mites are widely distributed in the environment $^{23}$ and that the positive skin response among bakers is an indicator of atopy rather than a response to a specific occupational allergen.

Personal atopy was significantly associated with skin sensitisation to occupational allergens, and more than $50 \%$ of the symptomatic subjects at work were atopic, confirming a sig- nificant role of host characteristic in the development of allergic disease from exposure to high molecular weight allergens. ${ }^{7-11}$

The part played by smoking in the cutaneous response to allergens and in occupational asthma is not clear. ${ }^{24}{ }^{25}$ In our study the association with sensitisation to wheat flour or $a$-amylase was important. Also, together with age, smoking was the only significant predictor of chronic bronchitis, whereas it did not seem to play a part in work related symptoms.

Our data on the prevalence of symptoms at work $(18.6 \%)$ and on asthma in particular (4.9\%) are similar to those of Prichard et al ${ }^{13}$ but higher than those of Rosemberg et al, ${ }^{14}$ and Musk. ${ }^{12}$ In evaluating the last study, however, it must be borne in mind that their data came from large bakeries, which had a selection policy of excluding subjects with current asthma from employment; our bakers, on the other hand, worked in small concerns where environmental exposure is certainly more difficult to control.

A healthy survival bias may play a significant part in occupational asthma ${ }^{1424}$ and in our study, the percentages of atopic and symptomatic workers, assessed according to work seniority, show a decrease in the groups with more than nine years of occupational exposure. Although we should exercise caution in evaluating these cross sectional data, they still seem to suggest that there are workers who leave the workplace because of their pronounced symptomatology.

Limiting environmental exposure to allergens is still the best preventive measure ${ }^{121325}$ although some data ${ }^{12}$ indicate that even in a modern bakery, control of dust exposure presents a continuing problem. Education in environmental prevention is particularly important in small businesses where the baking procedures are less automated, but we believe that greater care in identifying predisposed subjects is also necessary. Because atopy is a recognised risk factor for workers exposed to high molecular weight substances, this should influence the preventive measures to be adopted. Clearly, periodical medical checks should be performed, and the removal of symptomatic workers from the offending atmosphere is the treatment of choice. The exclusion of atopic subjects from bakery work is still a debated question ${ }^{79}$ because such a decision causes difficulties of relocation and unemployment. Because these are serious problems, especially for older workers, there is clearly a need for long term follow up studies and pre-employment screening, ${ }^{26}$ to better define the fate of atopic workers exposed to occupational allergens in the baking industry.

We thank our colleagues A Iob, $M$ Sigon, $M$ Treleani, and E Zamparo for their help in collecting the data.

1 Baggoe K. Mehlidiosynkrasie als Ursache von vasomotorischer Rhinitis und Asthma. Klinische Wochenschrif 1933;12:792-5.

2 Blands J, Diamant B, Kallos P, Kallos-Defner L, Lowenstein S. Flour allergy in bakers: identification of allergenic fractions in flour and comparison of diagnostic methods. International Archives of Allergy and Applied Immunology 1976;52:392-406. 
3 Baldo BA, Wrigley CW. IgE antibodies to wheat flour components. Studies with sera from subjects with baker's asthma or coeliac condition. Clinical Allergy 1978;8:109-24.

4 Thiel H, Zimmermann I, Rosche B, Ulmer W. Allergenspecific histamine release from whole blood in flour sensitive bakers. Respiration 1982;43:208-20.

5 Popescu IG, Ulmeanu V, Murariu D. Atopic and nonatopic sensitivity in a large bakery. Allergol Immunopathol

6 Revsbech $P$, Dueholm M. Storage mite allergy among bakers. Allergy 1990;45:204-8.

7 Nordman $H$. Atopy and preemployment screening. European fournal of Respiratory Diseases 1987;10:120-10.

8 Sunyer J, Anto' JM, Sabria' J, Rodrigo M J, Roca J, Morrel $F$, et al. Risk factors of soybean epidemic asthma-the role of smoking and atopy. Am Rev Respir Dis 1992; 145:1098-102.

9 Jarvinen K, Pirila V, Bjorksten F. Unsuitability of bakery work for a person with atopy: a study of 234 bakery work for a person with atopy: a studi
workers. Ann Allergy 1979;42:192-5.

10 Thiel H, Ulmer WT. Bakers' asthma: development and possibility for treatment. Chest 1980;78:(suppl 2):400-5.

11 Charpin D. Enquete épidémiologique chez les boulangers. Archives des Maladies Professionelles 1984;45:381-2.

12 Musk AW, Venables KR, Crook B, Nunn A J, Hawkins R, Crook G D W, et al. Respiratory symptoms, lung function and sensitisation to flour in a British bakery. $\mathrm{Br} \mathcal{F}$ Ind Med 1988;46:636-43.

13 Prichard MG, Ryan G, Musk AW. Wheat flour sensitisation and airways disease in urban bakers. $\mathrm{Br} \mathcal{F}$ Ind $\mathrm{Med}$ 1984;41:450-4

14 Rosemberg N, Rameix F, Demangeat G, Philippon J, Rigault M, Schlacther T, et al. Prévalence de l'allergie respiratoire dans la boulangerie-patisserie parisienne en 1987. Archives des Maladies Professionelles. 1991;52:33-6.

15 Sama' B. Aspetti assicurativi attuali in tema di asma bronchiale da farina di frumento nell'industria $e$ nell'artigianato. Atti Conv. "Cereali e sfarinati: rischi, patologia e strategie preventive nella realta' industriale ed artigianale". Venezia:10 April 1992.

16 Theobald $\mathrm{K}$. Thiel $\mathrm{H}$, Kallweit MD, Konig MD. Detection of proteins in wheat-flour extracts that bind human IgGm IgE and mouse monoclonal antibodies. $\mathfrak{F}$ Allergy Clin Immunol 1986;78:470-7.

17 Baur $X$, Sauer $W$, Weiss $W$. Baking additives as new allergens in baker's asthma. Respiration 1988;54:70-2.

18 Flindt MLH. Allergy to alpha amylase and papain. Lance 1979;6:1407-8.

19 Birnbaum J, Latil F, Vervloet D, Senft M, Charpin J. Role de l'alpha-amylase dans l'asthme du boulanger. Rev Mal Respir 1988;5:519-21.

20 Brisman J, Belin L. Clinical and immunological responses to occupational exposure to alpha-amylase in the baking industry. $\mathrm{Br} F$ Ind Med 1991;48:604-8.

21 Bermejo N, Maria Y, Gueant JL, Moneret-Vautrin D A Allergie professionnelle du boulanger à l'alpha-amylase fungique. Revue Francaise d'Allengol 1991;31:56-8.

22 Armentia A, Tapias J, Barber D, Martin J, de la Fuente $R$ Sanchez $\mathbf{P}$, et al. Sensitization to the storage mite Lepidoglyphus destructor in wheat flour respiratory allergy. Ann Allergy 1992;68:398-403.

23 Tee RD, Gordon DJ, Gordon S. Immune response to flour and dust mites in a United Kingdom bakery. Br $\mathcal{J}$ Ind Med 1992;49:581-7.

24 Chang Yeung M, Sverre V, Stephen L, Donald E. Immediate skin reactivity and its relationship to age, sex, smoking, and occupational exposure. Arch Environ Health 1985;40:53-7.

25 Vedal S, Chang-Yeung M, Enarson D, Fera T, Maclean L, Tse K S, Langille R. Symptoms and pulmonary function in western red cedar workers related to duration of employment and dust exposure. Arch Environ Health 1986;41:179-83.

26 R De Zotti, Larese F, Molinari S, Falagiani P, Colle B. Preemployment screening among bakers [abstract]. European fournal of Allergy and Clinical Immunology 1993;48(suppl 16):1076. 